\title{
Forging a Community with Rails: Ames, Iowa Agricultural College, and the Ames \& College Railway, 1890-1896
}

\section{DOUGLAS BIGGS}

USING RAILROADS to build or supplement the growth of urban communities was a common practice throughout the world in the last quarter of the nineteenth century. Paris, London, New York, Boston, Philadelphia, and other great cities used street railway systems to join their suburbs to the city center, which facilitated every aspect of economic and social life in the great urban environment. This was no less the case in the Midwest, where metropolises like Chicago as well as mid-sized cities like Omaha/Council Bluffs and Des Moines likewise used railways to join their suburbs to the city center. ${ }^{1}$ But the transformation of a small community by a local railroad could be just as significant, on a smaller scale, as shown by the impact of the Ames \& College Railway (A\&C) on Ames, Iowa, in the 1890s.

I would like to thank the staff at the Iowa State University (ISU) Library's Special Collections Department for their help when I conducted research for this article. Especially, I would like to thank Becky Jordan, who pulled many archival boxes for me and discussed issues at length. I would also like to thank my friend K. G. Madison, professor emeritus of history at ISU, for discussing the material herein. Last, and not least, I wish to thank my wife, Gloria Betcher, from the ISU English Department, who helped me form ideas and hone my argument.

1. E. Bryant Philipps, "Early Street Railways of Council Bluffs," Iowa Journal of History 48 (1950), 121-32; W. F. McGlothlen, “Des Moines Street Transit," Annals of Iowa 31 (1952), 225.

THE ANNALS OF IOWA 71 (Summer 2012). (C) The State Historical Society of Iowa, 2012. 


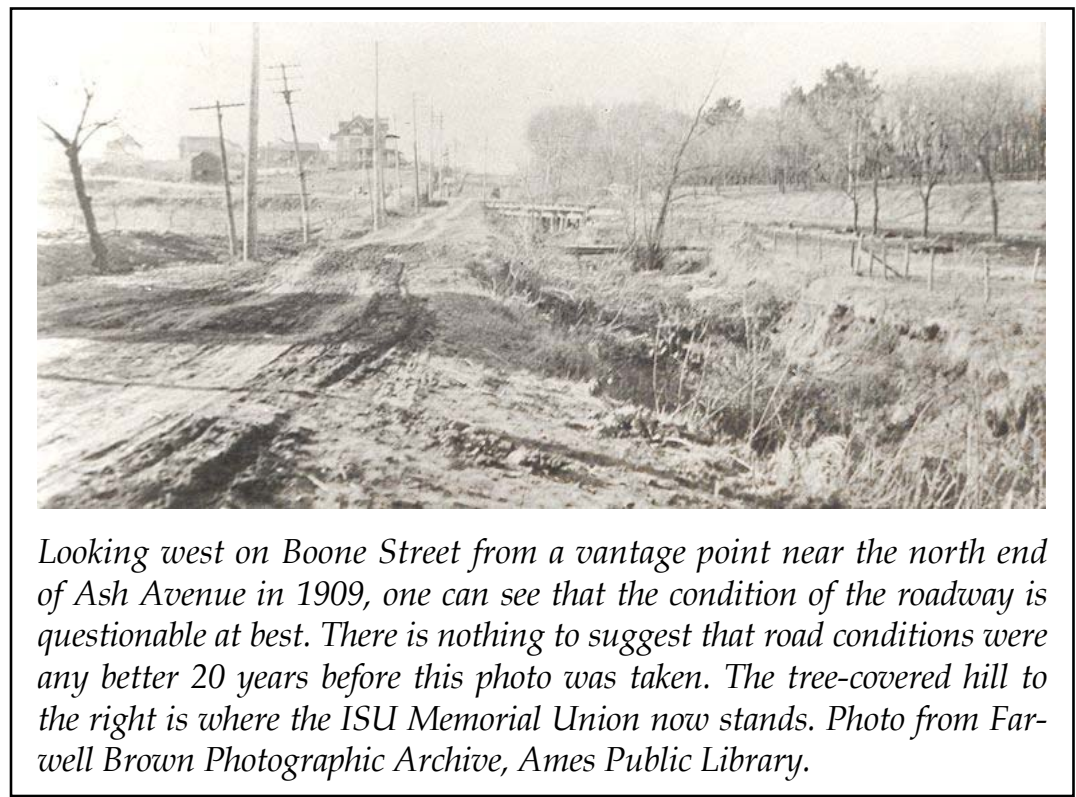

Before the construction of the A\&C in the first months of 1891, the city was separated from the Iowa State Agricultural College (IAC), two miles to the west, by the broad, shady bed of Squaw Creek. Prior to the building of the A\&C the only link between IAC and Ames was Boone Street, a mud track with a rickety bridge that became impassable during periods of heavy rain or snow. ${ }^{2}$ Although the main line of the Chicago \& North Western Railway (C\&NW) ran hard by the northern edge of IAC, failed negotiations between the college and the C\&NW in the 1870s and 1880s proved that the railroad would not build a new station or even a spur line to an agricultural college that had fewer than 300 students.

It was not until 1891, when the locally owned and operated Ames \& College Railroad, or the Motor Line, built a steam locomotive service initially with only one, small, steam-dummy en-

2. "As an example, this spring (1892) the [Squaw] Creek rose, in less than 48 hours, to such a height as to cover the entire bottom land, and did great damage by its washouts on the highway [Boone St.] and the motor line." George S. Foster, "Design of a Stone Arch Bridge across Squaw Creek, on C\&NW RR One Mile West of Ames" (unpublished undergraduate thesis, Iowa Agricultural College, 1892), 3. 


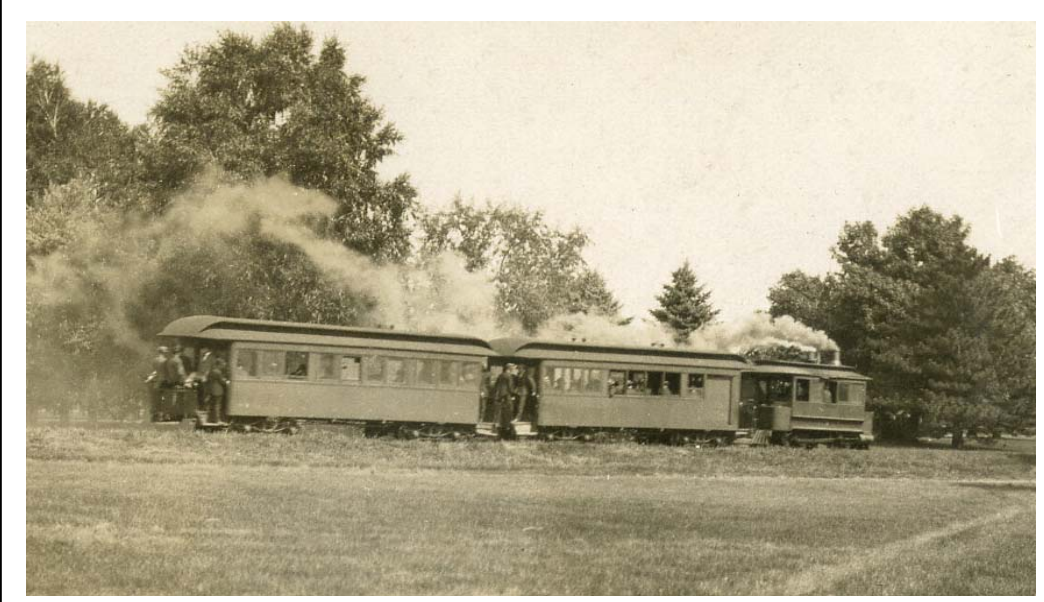

In this undated photograph, the Dinkey, hauling the "immigrant car" and one of its two regular passenger cars, steams across the park heading for downtown. Note the passengers standing on the platforms and on the stairs. Photo from Special Collections, Iowa State University Library.

gine and two passenger cars, that the communities of Ames and IAC were linked. The diminutive size of the engine and the cars, coupled with the fact that the train was slow, underpowered, and usually overcrowded, led IAC students and townspeople to derisively refer to the train as "the Dinkey," and the name stuck. The first and only reliable rapid transit link between IAC and Ames until Boone Street was paved after World War I, the steam Dinkey made round trips from 1891 to 1907, before it sold out to the larger electric interurban railway, the Ft. Dodge, Des Moines \& Southern, which replaced the steam locomotive with an electrified streetcar.

For a brief period, however, between 1891 and 1896, the Ames \& College Railway had a significant impact on the citizens of Ames and the students of IAC. Those early years saw the railroad's founding and development but also the shaping of the community of Ames. After 1896, technological and progressive reforms in the city of Ames, such as electricity, an improved water and sewer system, and a new C\&NW depot, rendered the once transformative Motor Line obsolete. Still, local 
Ames historians have long noted the Dinkey's central place in uniting the town with the college and in forging one community. ${ }^{3}$

This article will examine the first five years of the A\&C's operations, focusing on three points. First, the A\&C came about through a confluence of student and capitalist effort, led by Judge John Loomis Stevens, an alumnus of IAC's first graduating class of 1872. Even though the investment group did not possess the resources to build the electric street railway that he wanted, Stevens would not be defeated. Through sheer force of will, he pursued his dream with dogged determination; he purchased used steam equipment, which was all his company could afford, and convinced a skeptical IAC board of trustees that his plans would succeed.

Second, building the Motor Line had an immediate and profound impact on both Ames and IAC. Since the founding of both entities, they had been two communities, but the Motor Line transformed them into one community. The Dinkey allowed students and faculty to live in town and commute to the school. Townspeople could attend college lectures and performances in large numbers, while students could travel to town to purchase goods from Ames merchants. Thus, the $A \& C$ brought IAC to the world and the world to IAC, and Ames rapidly became a "college town."

Third, contemporaries recognized the role of the Motor Line within their community. IAC students wrote about the Dinkey in their yearbook, The Bomb. The little train made its way into their poetry and faux plays, along with figuring prominently in their retrospectives. Townspeople, too, clearly understood that the $\mathrm{A} \& \mathrm{C}$ formed the glue that held their community together, becoming an indispensable part of their world. "Without the Dinkey," one contemporary Ames citizen observed, "everything would stop."

3. William Orson Payne, History of Story County: A Record of Settlement, Organization, Progress and Achievement, 2 vols. (Chicago, 1911), 1:486-87; Gladys Meads, At the Squaw and Skunk (Ames, 1955), 142; Farwell Brown, "Ames' First Depot," in Ames: The Early Years in Word and Picture: From Marsh to Modern City (Ames, 1993), 19-23; idem, "When the Railroad Depot Was the Grand Portal to Our City," ibid., 170; idem, Ames: A Ride through Ames on the Dinkey (Charleston, SC, 2001). 
CONTEMPORARIES UNDERSTOOD the need for reliable rapid transit to and from IAC almost immediately after the first students arrived on campus in the autumn of 1868, but a number of economic, political, and geographical obstacles stood in the way of achieving that goal. The model farm and agricultural college were platted in 1858 on the high prairie in the western part of an isolated and sparsely populated part of Story County. 4 When John Insley Blair brought his Chicago \& North Western Railway's main line through the central part of the state in 1864, he wanted to place a station near the college, but Blair was not willing to pay the prices local landowners demanded, so he built his station, which he named in honor of his friend Congressman Oakes Ames, roughly two miles to the east of the college in the swampland near the confluence of the Skunk River and Squaw Creek. ${ }^{5}$ In the succeeding years, although the C\&NW main line ran tantalizingly close to the northern border of campus, repeated negotiations between the railroad and the college demonstrated that the C\&NW had no interest in building a station at the college or even constructing a spur line to deliver goods and students. ${ }^{6}$ Thus, the college remained a tiny community isolated on the high prairie two miles west of Ames separated by the Skunk River.

If the college found itself all but alone, Ames Station-or "Ames," as it soon became known-lay in a sort of "no man's land" between two larger communities. Fifteen miles to the east on the C\&NW main line was Nevada, the county seat, with the courthouse, the only newspaper in the county until 1877, and a thriving business district. Roughly 15 miles to the west of Ames, across the Story County line, was the bustling community of

4. The college and model farm originally comprised 648 acres of prairie. It was located in the western part of the county because Boone County had put up a significant portion of the funds to purchase the land and because Nevada (the county seat of Story County and largest town in the county) did not really want the college physically nearby. Payne, Story County, 1:15-16; Earle D. Ross, A History of Iowa State College (Ames, 1942), 27-29, 167.

5. Farwell Brown, "Ames' First Depot," 19-23.

6. In May 1882 IAC's board of trustees ordered President A. S. Welch to close on negotiations with the C\&NW on the construction of a spur line that would link IAC to the company's main line. Board of Trustees, vol. 3, May 2-5 and May 23-26, 1882, Special Collections, Iowa State University Library. 
Boone. It sat on the eastern edge of some of Iowa's richest coalfields, was the county seat of Boone County, and served as a major repair center for the C\&NW. Ames's growth and viability were compromised not only by its location, but even more by the land on which it stood: bottom land that did not endear the little town to its early residents, who noted that the town's streets were more often sloughs than thoroughfares and that the C\&NW station resembled a line shack more than a depot. ${ }^{7}$ The city council's failure to curtail chickens and dogs roaming free in the town did little to inspire hope that Ames would attract many new residents or be anything much more than a stopping point for Blair's trains to take on water and coal. ${ }^{8}$

Although the City of Ames and IAC were each keenly aware of the other's presence in the 1860s and 1870s, the first regular transportation service between the college and the city did not appear until August 1874. A horse-drawn bus ran three return trips to campus per day, but was uncomfortable, unreliable, and expensive at 10 cents per ride. The service could be interrupted for days or even weeks at a time when heavy rains or snows made Boone Street impassable. Contemporaries considered the bus service better than nothing, but even the addition of a second bus in the 1880s could not provide the college with the transportation and freight services that it needed. ${ }^{9}$

Throughout the 1880s, as IAC's enrollment grew to nearly 300 students, the administration faced calls from the faculty and the student body to build or contract for a regular and reliable mode of transit between the city and college. All parties agreed on the necessity to improve the transportation system, but in

7. Payne, Story County, 1:324-28; Brown, Ames: The Early Years, 14.

8. An ordinance restricting dogs running loose was approved on May 2, 1870. City of Ames, City Council Minutes, 5/8/1870, book 1, part 1, p. 35. A similar ordinance in regards to chickens running loose received unanimous council approval on May 15, 1871. City of Ames, City Council Minutes, 5/15/1871, book 1, part 1, p. 85.

9. Payne, History of Story County, 1:437. The Aurora, August 1874, noted briefly and simply, "Here at Last! The new college bus." The bus continued to run long after the Motor Line was established in 1891. As late as 1893, student groups rented the bus to go between campus and town. Ames Times, 10/5/ 1893. Later that same month Billy Childs, the owner and operator of the bus, was seriously injured when he was kicked by a horse. Ames Times, 10/19/1893. 
spite of much talk no one could find a workable solution to the transportation problem. ${ }^{10}$ Internal difficulties in both communities were largely responsible for the inability to build a better transportation link between IAC and Ames in the 1880s. IAC underwent a series of internal crises throughout the decade and went through five different presidents between January 1881 and January 1891. ${ }^{11}$ The town, meanwhile, had seen some promising progress in the first half of the decade, but then suffered three devastating fires in 1886 and 1887 that destroyed nearly the entire business district. Thus, all available capital in the local banks and energy from Ames capitalists were tied up in rebuilding the downtown. ${ }^{12}$ Finally, in the spring of 1890 a timely confluence of IAC student energy and the vision of an alumnus from IAC's first graduating class provided the will to build a rail link between the college and city.

IN THE AUTUMN OF 1889, two junior electrical engineering students, J. A. Bramhall and C. D. Davidson, proposed a joint senior thesis topic that ended up serving as a feasibility study for the construction of an electric railway between Ames and IAC. In the 1880s electric railways were still in their infancy. As with all new technology, electric rail systems were expensive and the technology could be tetchy. Notwithstanding the cost or difficulties, smaller Iowa towns strove to bring the status symbol of electricity to their street railways throughout the 1880s. Fort Dodge's experience exemplifies how difficult electrifying a street railroad could be. Even though Fort Dodge, 60 miles north-

10. As early as 1880 faculty were petitioning the college trustees to provide better transportation for the faculty who lived in town. Ross, History of Iowa State, 168. The authors of an 1890 study of the potential for a rail link between the town and the college stated that they selected their topic because "the question of quick and efficient communication between Ames and the college, is one that has occupied the thoughtful attention of the college trustees, faculty, and business men of Ames for several years," though "in a vague and uncertain way." J. A. Bramhall and C. D. Davidson, "Electrical Railroad between Ames and the College" (undergraduate thesis, Iowa Agricultural College, 1890), 1.

11. Ross, History of Iowa State, 122-24. For a more detailed account of the issues within IAC in the 1880s as it related directly to the teaching of agriculture, see John Boyd Hungerford, "Sketches of Iowa State College," Special Collections, Iowa State University Library, 143-49.

12. Meads, Squaw and Skunk, 117-18. 
west of Ames, had a population of over 4,800 in 1890, the town did not possess the economic resources necessary to achieve the goal of an electric railway until 1896.13 As Carl Condit suggests, electric railroads "were feasible only in areas of the highest population, traffic and commercial density." 14 Ames, with a population of only 1,276 in 1890, did not have electricity in the town and was not financially able to build an electric plant until 1896. Thus, what the students proposed was a very ambitious scheme that generated excitement on campus and in town.

The junior class of civil engineers became involved in the project by performing the survey work for the route of the proposed railroad. The students surveyed the route across campus and through the Squaw Valley, where they proposed to build three bridges: one in iron to span the Squaw Creek main channel, a second to cover the back channel, and a third to cross a small estuary that fed the creek. The route then proceeded east to Ames through the heart of the business district and terminated just north of the C\&NW depot. This 1.98 miles of rail would link the heretofore isolated college to the rest of the world.

Conscious that their railroad would need to deliver freight to the college and model farm, Bramhall and Davidson adopted a standard gauge. This forced certain expenses on them, but they found several creative ways to keep the total cost down. First, they proposed buying only one engine and two passenger cars. Because they estimated that their train would carry no more than 10,000 passengers annually, they proposed running the railway on only a part-time business, roughly 230 days a year, to help keep costs down. The students also envisioned a part-time board of directors and a part-time business manager and suggested that employees would be necessary only when the train ran. ${ }^{15}$

The alumnus and self-styled progressive who provided the capital and the will to execute Bramhall and Davidson's plan

13. Albert Butts, The Story of the Fort Dodge Street Railway System (Webster City, 1981), 10. As Butts demonstrates, although the city purchased some of the equipment necessary for the electric line in 1894, costs kept the city and investors from completing the line until 1896.

14. Carl Condit, "The Pioneer Stage of Railroad Electrification," Transactions of the American Philosophical Society 67/7 (1977), 7.

15. Bramhall and Davidson, "Electrical Railroad." 
was Judge John Loomis Stevens. The railroad business ran deep in the Stevens family. John's father had worked for the railroad all his adult life, and John himself had briefly worked for railroads after graduating from IAC in 1872 before turning to the law in the mid-1870s. He settled in Ames, opened a legal practice, involved himself in city government, and then became a circuit judge in $1886 .{ }^{16}$

Exactly what moved Stevens to take notice of Bramhall and Davidson's work is unknown, but perhaps the catalyst for his keen interest was the visit to Ames by a Davenport company seeking to build an electric railroad between Ames and the college. ${ }^{17}$ The city of Ames and its citizens disliked what they termed "foreign companies" descending on the community, establishing businesses, and taking profits out of town. ${ }^{18}$ Stevens shared his fellow citizens' biases, so the visit from the Davenport street railway company might well have moved him to action.

Whatever the case, Stevens, seing the potential to capitalize on the students' project, helped Bramhall and Davidson with their research by paying for various things out of his own pocket with an eye toward eventually building the railway the students proposed. Stevens quickly realized, however, that funding the project beyond the research phase lay beyond his personal means. To share the cost of building the railroad, he organized three fellow IAC graduates into a group of investors and in September 1890 incorporated the group as the Ames Street Railway Company, which eventually became the Ames \& College Railway. ${ }^{19}$

16. For a fine biographical study of Stevens, see Suzanne Caswell, “John Loomis Stevens: A Biographical Sketch," Trail Tales: The Journal of Boone County History 109 (2008), 17-40.

17. Ames Intelligencer, 5/15/1890. Davenport reached a population of 27,000 in 1890 and had established an electric railway system in 1888. William Thompson, Transportation in Iowa: A Historical Summary (Des Moines, 1989), 116.

18. In a letter to the editor in the Ames Times, a citizen wrote that he disliked the idea that a "foreign company" would have to come in with the resources necessary to provide electric power, but the writer agreed that there seemed to be no alternative. Ames Times, 2/28/1895.

19. The A\&C reported September 9, 1890, to the Railroad Commission as the founding date of the railroad. Nineteenth Annual Report of the Board of Railroad Commissioners for the State of Iowa for the Year Ending, June 30, 1897 (Des Moines, 1897), 183. The articles of incorporation were signed in Boone before George Crooks on September 20, 1890, and filed with Story County on October 7, 1890. 
The prospect of an electric railway connecting the college to the city generated a good deal of coverage in the local newspapers in the autumn of 1890. In spite of the enthusiasm and Stevens's progressive desires, however, the four initial investors in the $A \& C$ found the cost of building and operating an electric railway far beyond their means. Stevens would not be deterred, however. He was far too shrewd a businessman to let slip that he could not afford an electric railroad. Any such admission would have dampened community support.

Although the A\&C proposal allowed the city and college media to tout a new electric line, Stevens never revealed the specifics of his plan in official negotiations. In September he sought a license from the city council to run his railway-powered by electricity, steam, or animal power at the company's discretiondown Ames's streets. The city agreed to his proposal, approving Ordinance \#94 with alacrity in October after only two readings. The city council also gave the A\&C a 30-year monopoly on operating a street railway in Ames. ${ }^{20}$

Convincing the city to give the $\mathrm{A} \& \mathrm{C}$ the right to construct its road and give it right-of-way to run trains along Ames's streets proved easy in comparison to obtaining similar permission from

Story County, Iowa, Recorder's Office, Misc. Book 8, pp. 585-89; Brown, The Early Years, 42n. On November 24, 1890, Stevens sent a copy of the articles of incorporation to Secretary of State F. D. Jackson, asking him to file the articles with the state and bill him for the charges. Six days later, on November 30, Stevens duly sent a check for $\$ 7.10$ for filing fees. Author correspondence with State Historical Society of Iowa, Des Moines. The articles were copied into the Secretary of State's records on December 3, 1890, and the originals were returned to Stevens by mail on December 12. Secretary of State, Iowa, Book D-2, pp. 303-6, State Archives, State Historical Society of Iowa, Des Moines. The other original investors in the A\&C were Robert J. Hopkins, Richard Jordan, and Joseph Whitaker. Hopkins, from nearby Madrid, graduated from IAC in 1881 and was a banker as well as clerk of court for Stevens from 1888 until his untimely death in 1893. Goldthwait, A History of Boone County, 2 vols. (Chicago, 1914), 1:231; Elizabeth Tiernan, Iowa State College Graduates: A Biographical Dictionary, 1872-1889 (Ames, 1939), 28. Jordan, who graduated from IAC in 1877, was a Boone attorney. Goldthwait, History of Boone County, 2:91; Tiernan, ISC Graduates, 1872-1889, 16. Whitaker, who graduated from IAC in 1874, was a Boone attorney and lifelong friend of Stevens. Goldthwait, History of Boone County, 2:48-51; Tiernan, ISC Graduates, 1872-1889, 8; Ames Daily Tribune, 10/26/1933.

20. Ames City Council Proceedings, 1880-1891, book 1, part 2, pp. 265-70. See also Ames Intelligencer, 10/23/1890. 
IAC. In November 1890 Stevens presented the trustees with a proposal very different from the one he had presented to the city council; he now proposed a horse-drawn railway to connect the college and the city. The trustees, unmoved by civic enthusiasm or student research, were skeptical of the enterprise. Simply put, they did not believe that the investors possessed sufficient capital to successfully build and operate such a business. ${ }^{21}$ The trustees also considered a horse-drawn railway insufficient to meet the college's transportation needs. ${ }^{22}$ Despite the rebuff, the trustees agreed to continue a dialog with Stevens concerning his proposal over the holiday season of 1890-91. The substance of the dialog in those weeks is lost to us, but a couple of important things happened. First, Stevens broadened his investor base by selling shares of stock in the company to important college and city folk. Second, as the investors could not afford electricity and the IAC trustees would not allow them to use animal power, they turned to steam as the source of motive power.

By 1890, steam was fast being replaced by electricity in street railway systems, but if Stevens wanted his dream to become a reality, steam was the only source of motive power that the $\mathrm{A} \& \mathrm{C}$ could afford and that the trustees would accept. Perhaps nothing better demonstrates the undercapitalized nature of the $A \& C$ than the company's inability to afford anything more than one used engine and two used 32-foot passenger cars in the beginning, and it could only afford to lay 30 -pound rails, which were not really sufficient for the task at hand. Not surprisingly, the $A \& C$ found that the rails often split, the trains often derailed if they went over 10 miles per hour, and the roadbed was in constant need of maintenance.

21. It is an interesting irony that William McElroy served on the trustees' subcommittee to help create the Ames \& College Railway in 1890 and was also instrumental in mandating changes that forced the A\&C to sell itself to a larger railroad in 1905. In fact, it is Trustee McElroy's retrospective in 1905 that sheds light on the board's position on the A\&C in 1890. Board of Trustees Reports, Book C, July 1903-January 1907, pp. 369-72, Special Collections, Iowa State University.

22. Ames Intelligencer, 11/13/1890. The board of trustees' records show that the date on which the trustees discussed the A\&C's proposal was November 12. Board of Trustees, vol. D, May 1888-May 1894, p. 146, Special Collections, Iowa State University Library. 
However obsolete, the little steam train gave students, faculty, and visitors a reliable transit between Ames and IAC. No matter how bitterly contemporaries complained about the train, they all agreed that the Dinkey was better than the expensive horse-drawn bus and far better than walking. An increased investor base and the decision to employ steam power convinced the trustees to give Stevens and his railroad a chance. In January 1891 they issued the first of a series of two-year contracts that gave the $A \& C$ the right to run its train across campus along a route already surveyed by Bramhall and Davidson, and gave the company a monopoly on freight and mail service to the college. ${ }^{23}$

Despite the terms of the agreement, Stevens soon found that IAC's new president wanted changes to the route across campus that he had helped Bramhall and Davidson survey. This rerouting of the tracks by William Beardshear, who became president of IAC in February 1891, was only the first indication of the deep impact the president would have on the A\&C. ${ }^{24}$ Even though the January agreement between the trustees and the A\&C stipulated that the on-campus portion of the railroad follow the route already surveyed by Bramhall and Davidson, in May 1891 the trustees set a committee of the recently arrived President Beardshear along with professors D. W. Church and "Tama" Jim Wilson to determine a new route for the track on campus. ${ }^{25}$ The president's committee followed the students' survey at first by taking the rails up the grade from the Squaw Valley between IAC's farmhouse and barns but then ran the

23. Board of Trustees, vol. D, May 1888-May 1894, 1/9/1891, pp. 159-60, Special Collections, Iowa State University Library.

24. Beardshear was born in Ohio in 1850 and had become president of Western College in Toledo, Iowa, before moving on to become the superintendent of public schools in Des Moines in 1889.

25 . The trustees told the committee that they could change the route, "provided that the location of the new railway as it enters the campus proceed by what had previously been the north driveway of the college grounds." Board of Trustees Reports, vol. D, May 1888-May 1894, 5/14/1891, pp. 237-38, Special Collections, Iowa State University. The charge to the president's associates is printed in the Fourteenth Biennial Report of the Board of Trustees of the Iowa State Agricultural College and Farm Made to the Governor of Iowa (Des Moines, 1891), 142. There is, however, no mention of it in Beardshear's annual report to the college trustees dated June 15, 1891, in folder $1 / 2$, box 1, RS 2/5, William Miller Beardshear Papers, Special Collections, Iowa State University Library. 


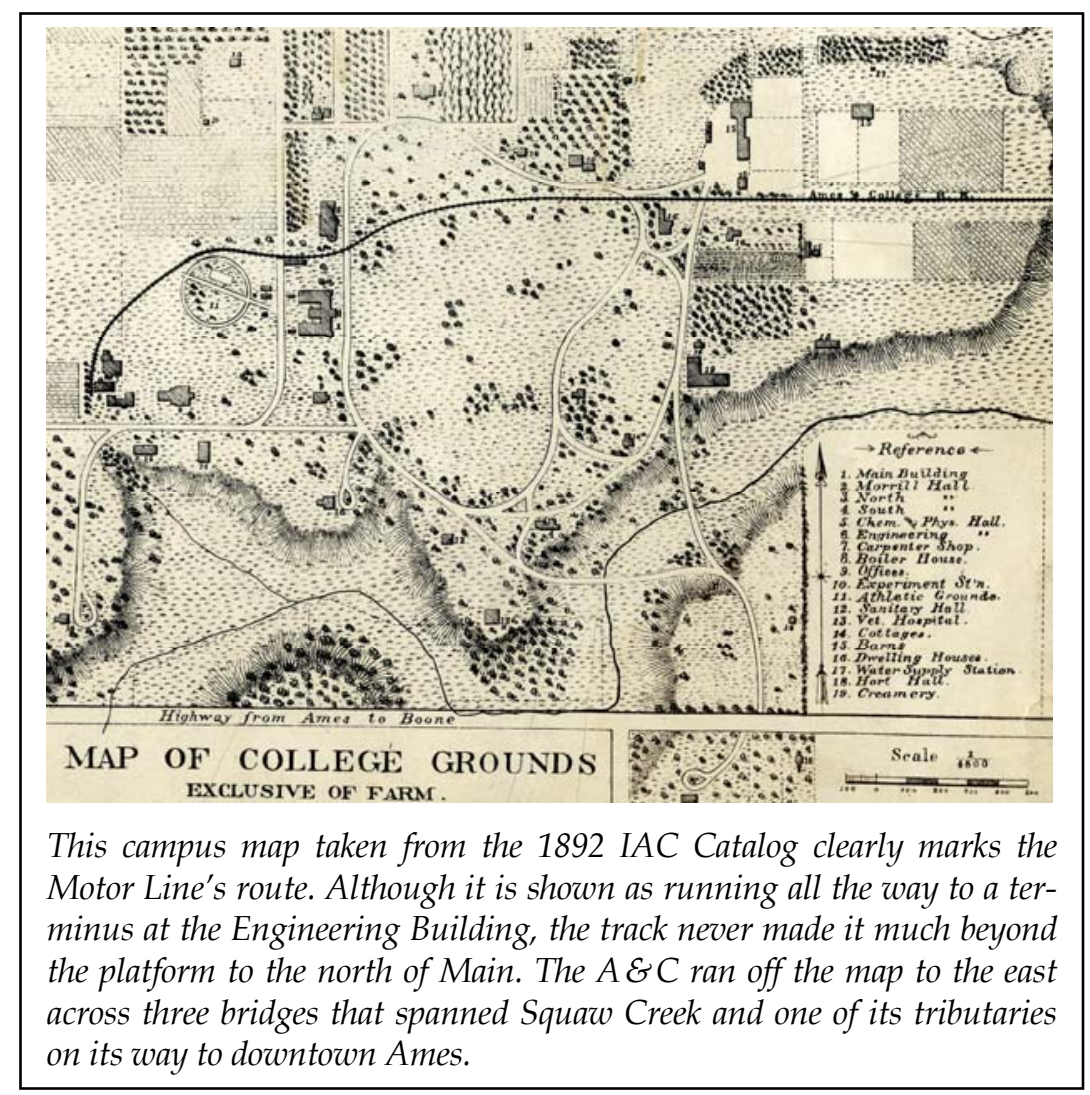

track through the northern shoulder of the "park," as contemporaries referred to the large green space dotted with small groves of trees between the east front of Main and west of the Farm House (now called "Central Campus"), rather than on the northern fringe, where Bramhall and Davidson had planned it. Then it proceeded slightly to the south into the very heart of campus, where it terminated between Main and Morrill Hall, rather than behind Main as Bramhall and Davidson had planned.

The decision to change the route at this stage was not arbitrary. The president understood from the outset that the Motor Line would be much more than merely a train; it would be the vehicle that would deliver tens of thousands of students, alumni, and visitors to the campus in the coming years. For many of these men and women, their first introduction to college would be the view of campus from the A\&C's cars as the train cleared 


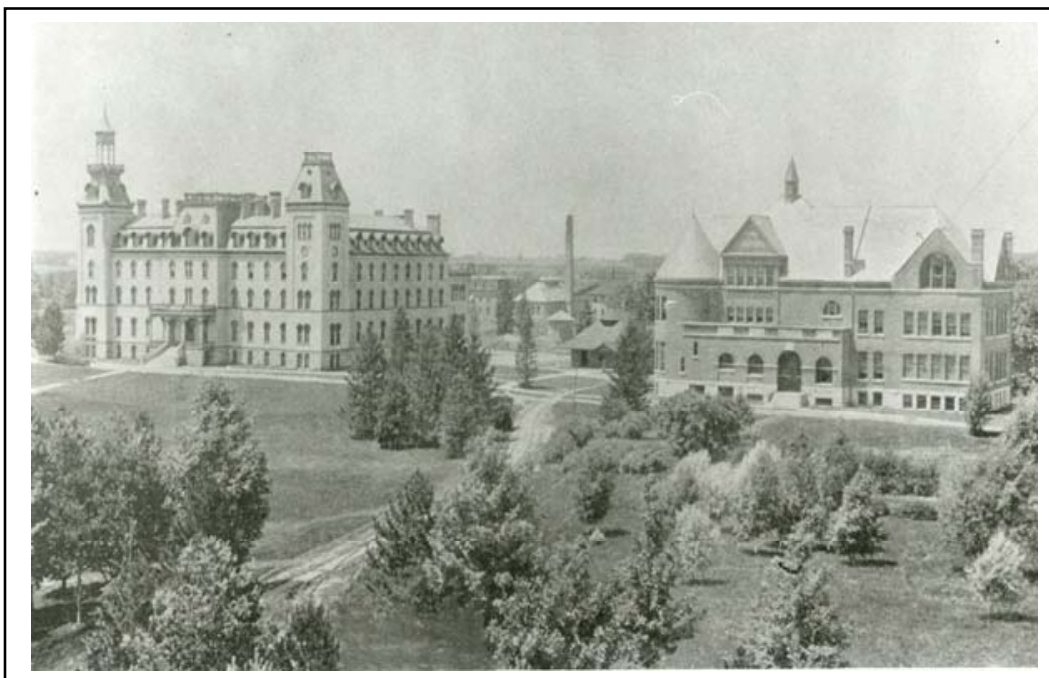

For about a decade this represented the view of the eastern face of the ISC campus. Main is on the left, with Morrill Hall on the right and the Hub (the campus terminus for the Dinkey) in the middle. The Dinkey line is in the center of the photograph running through the park towards the Hub. Although the picture is taken from the porch of the new Agricultural Hall (now Catt Hall), it gives some idea of the view of these buildings from the Dinkey as it cleared the farm and steamed for the heart of campus. This photograph is the frontispiece to the Fifteenth Biennial Report of the Board of Trustees of the Iowa State Agricultural College and Farm Made to the Governor of Iowa for the Years 1892 and 1893 (Des Moines, 1893).

the college farm, and Beardshear intended for that first view of the eastern face of campus to leave a lasting impression. ${ }^{26}$

Beardshear's new route ensured that the visitors to his campus were treated to a striking view of the park, contrasted with the five-story Main, resplendent in her coat of white paint, and the rich red brick of Morrill Hall, both of which seemed to rise right up out of the prairie. The train finished its journey in between these two, and when the passengers alighted from the

26. Beardshear well understood the value of grand buildings. As he himself wrote, "Buildings and improvements talk without words." Special Report to the Trustees, 11/16/1897, box 1, RS 2/5, Beardshear Papers. D. A. Thornburgh, from the class of 1892, remembered how as a freshman he "marveled at the size of the 'old Main,' and drank in the beauty of that matchless campus." The 1908 Bomb. 
cars, the two largest and most impressive structures on campus loomed over them. Many of those who came from farms and small towns to IAC in those years had never seen buildings this grand. ${ }^{27}$

With the route across campus determined, construction on the line began in April 1891. Even though Stevens had broadened his company's investor base, his railway remained an undercapitalized venture that could afford only a hastily built roadbed for the 1.98 miles of track, one used steam dummy engine, and two used street passenger cars. In spite of these shortcomings, the Motor Line began regular operations on July 4, 1891. For IAC's students, faculty, and staff, the city of Ames, which had been providing slow and unreliable transit service at the rate of ten cents per bus ride, was now only eight minutes away at half the cost. It is not surprising, therefore, to find that the two communities rapidly came together.

RIDERSHIP STATISTICS demonstrate just how quickly the A\&C created one community and sustained what it had created. The founders of the railway had envisioned a part-time railroad that would carry perhaps 10,000 passengers per year. To that end the $A \& C$ began with a modest service. The first timetable for the Motor Line shows that the railroad ran only 11 trains per day Monday through Saturday with another 6 trains on Sunday. But it was soon clear that this level of supply would not meet demand. After only one week in operation with the first schedule, the A\&C issued a revised timetable that nearly doubled service to 20 trains per day Monday through Saturday and 6 trains on Sunday. The first six months of operations exceeded

27. In spite of many modifications to Iowa State's campus, this part of Beardshear's vision of the college remains largely intact well over a century later. The view of what is now known as central campus from the western end of the farmhouse is still considered striking by students, alumni, and visitors alike, as well as being considered worthy of awards for design by national associations of landscape architects. For example, Thomas Gains, in The Campus as a Work of Art (New York, 1991), proclaimed Iowa State one of the 25 most beautiful campuses in the country. In 1999 the American Society of Landscape Architects selected central campus as a "Medallion Site" as one of the 300 most significant landscaped sites in the country. www.lib.iastate.edu/ spcl/exhibits/150/template/campus.html (accessed 12/9/10). 
all expectations. By the end of December 1891, almost 40,000 passengers had paid their nickel to ride the train, and by the end of the fiscal year, June 30, 1892, the total ran to over 77,000 passengers - nearly eight times what the founders had expected at the Motor Line's inception. ${ }^{28}$

Qualitative evidence complements the quantifiable evidence that the $\mathrm{A} \& \mathrm{C}$ was facilitating interchange between the two communities. One of the most significant experiments in community building in the first year of the Dinkey's existence was the creation of the Campus Choral Club under the direction of Elaine Chambers. In the August 6 edition of the Intelligencer, Chambers announced the formation of the Choral Club on campus, with its first meeting set for August 13. The announcement noted that "a number of ladies and gentlemen in Ames have expressed a desire to become members. Miss Chambers hereby extends them an invitation to do so." To help promote Chambers's effort to include community members in the Thursday night meetings, the Motor Line agreed to make two or three extra trips to campus on those Thursdays. The only stipulation was that at least 20 people needed to take advantage of the service to make the trips "sufficiently remunerative." These trips clearly brought in sufficient revenue, for stories and advertisements in the paper demonstrate that many townspeople headed to campus on Thursday evenings throughout the autumn of 1891.29

Just as the Motor Line carried Ames residents to IAC, it also carried students to downtown Ames, where they spent money in the local businesses. ${ }^{30}$ In October 1891 the Intelligencer reported with its tongue firmly planted in its cheek that "some of the boys [at the college] say it would be cheaper for them if the motor would discontinue the night trips." 31 In November a

28. Ames Intelligencer, 7/16/1891, 7/23/1891, 1/14/1892; Fifteenth Annual Report of the Board of Railroad Commissioners of the State of Iowa for the Year Ending June 30, 1892 (Des Moines, 1892), 671.

29. Ames Intelligencer, 8/6/1891, 8/13/1891, 9/17/1891, 9/24/1891.

30. To take only one example, contemporaries themselves noted how much money could be spent by students downtown on a spur-of-the-moment basis. In recounting the most important events of the year, The 1894 Bomb, 149, noted that on May 5, 1894, several students, being "heavy of pocket and light of foot," went into town, danced the night away, and returned to campus much poorer.

31. Ames Intelligencer, 10/8/1891. 
group of students with a band from the college came to town and held what the paper described as an "impromptu Republican meeting" at the home of Captain Wallace Greeley, the town's most prominent Republican. ${ }^{32}$ Perhaps the most significant indicator of the Motor Line's impact on the town and college is that by October 1891 both the Intelligencer and the student newspaper, the IAC Student, stopped reminding their readers that the Dinkey would be carrying passengers to city and college events; within four months the novelty had become an accepted part of the community.

In addition to carrying passengers to visit the town or the college, the A\&C also helped to ease the overcrowded conditions of student housing on campus. As far back as 1886, ISC President William Chamberlain had pressed the legislature for funds to build new dormitory space on campus to alleviate overcrowding. At that point all of the students were housed in Main, which had originally been designed to house the president, the faculty and their families, and only 100 students. This initial design proved inadequate and had been amended by 1865 to house 162 students. The addition of new wings in 1872 further increased Main's dormitory capacity to 350 students. But by 1891 the student body had reached 425 with no downturn in sight, forcing the college to amend its housing policy and allow students to live off campus. Since IAC's inception, its policy had required all students to live on campus, but the presence of the Motor Line allowed increasing numbers of students to live downtown, thus alleviating the overcrowded conditions on campus. In 1895 the college built Margaret Hall, the women's dormitory, and renovated Main, allowing the college to house about 500 students. Even so, many IAC students continued to live in town and commute to campus daily. ${ }^{33}$

The men who governed the city had understood the importance of the A\&C from its inception. In the last months of 1892, as the little train became the backbone that joined the city to the college, they decided to extend the city limits to the west and annex the college to Ames. Throughout the autumn of 1892

32. Ames Intelligencer, $11 / 5 / 1891$.

33. Henry Summerfield Day, The Iowa State University Campus and Its Buildings (Ames, 1977), 322-35, 337-38. 
both Ames papers had been asking their readers to push the city council to annex the college into the city of Ames. Robert Armstrong of the Times wrote a brief editorial in the October 23 issue, noting the improvements on the IAC campus and commenting that "we want people to be here to educate their sons and daughters." On November 17 the Times stated the case for annexation in no uncertain terms: the college "rightfully belongs to us and this [annexation] would make us a city of second class in short order." 34 That is, bringing the college into Ames would add a substantial number of new citizens and increase the town's population so that Ames would rise to the status of a "City of the Second Class." As a result, more county dollars would flow into the city coffers, eventually allowing the city council to build a jail, levy bond issues to build or supplement existing water works facilities, and hire a town marshal. 35

Throughout the autumn, Mayor Parley Sheldon worked through the process of annexing the college and a portion of the land around it. On November 22 the city council considered the issue and instructed the city attorney to take the necessary steps to secure the annexation. On December 5 the council resolved to put the question of annexing the college and the land around it to the electorate in a special election that would take place on December 31. Mayor Sheldon's announcement of the election went in the Ames papers on December 8, and both papers urged their readers to support the resolution. One last salvo of media support came in the December 15 edition of the Times, which noted that the extension of the city limits would bring two miles of railroad inside the incorporated city limits, "the taxes from which would be no small matter." 36

As things turned out, the newspapers need not have spilled so much ink on the issue. When the votes were counted, 3 ballots were termed as "lost," 9 men voted no, and a whopping 129

34. Ames Times, 10/23/1892, 11/17/1892.

35 . The definitions, duties, and responsibilities of first-class and second-class cities were contained in statutes that had been passed by the state legislature in 1888. McLain's Annotated Code and Statutes of the State of Iowa, 4 vols. (Chicago, 1888), 1:197-200.

36. City of Ames, City Council Minutes, book 1, part 3 (1891-1901), 45-48; Ames

Times, 12/8/1892, 12/15/1892; Ames Intelligencer, 12/8/1892. 
votes were cast in favor of annexing the college to the city of Ames. In November 1893, when the secretary of state's office censed Ames's population to certify its status as a "City of the Second Class," it found 2,489 people in the city, including IAC's 620 students. That put Ames comfortably above the 2,000 population necessary to achieve such a status. ${ }^{37}$

Annexation increased the strength of the bond between the city and the college, and all three-Ames, IAC, and the A\&Cfacilitated that growth and profited from it. The railroad experienced no decline in demand for its service, carrying 77,000 passengers in the 1891-92 fiscal year. That number increased to 98,000 the next year, when the A\&C continued to run 20 trains per day Monday through Thursday, but expanded its timetable to 24 on Friday and Saturday (with only 4 on Sunday). Although the economic downturn known to contemporaries as the Panic of 1893 affected the Ames community, ridership on the A\&C remained robust. On virtually the same timetable adopted in March 1893, ridership dipped to 71,000 in FY 1893-94 but rebounded to 78,417 in FY 1894-95 (see table). The A\&C ran an average of 22 trains per day in those years but often supplemented its service with "special motors." In fact, "special motors" became so much the norm that the IAC Student noted in November 1894 that there had been one every night the previous week because there were 13 entertainments for college and Ames people. 38

While the $A \& C$ based most of its business on passenger traffic, that only accounted for part of the company's income. The line had a monopoly not only on hauling the mail to campus twice per day, but it also held the monopoly on freight service. The trustees negotiated freight service as part of the contract with the railroad in 1891 at the flat rate of 25 cents per ton. In FY 1893-94 the Motor Line hauled over 8,000 tons of freight to cam-

37. City of Ames, City Council Minutes, book 1, part 3 (1891-1901), 48-53. Ames conducted a special census on October 30,1893, and the findings were forwarded to the secretary of state. On November 13, 1893, the secretary of state sent an official memo to Ames codifying its position as a "City of the Second Class." State of Iowa, Secretary of State, 11/13/1893, Secretary of State's Office, Des Moines.

38. IAC Student, 11/6/1894. 


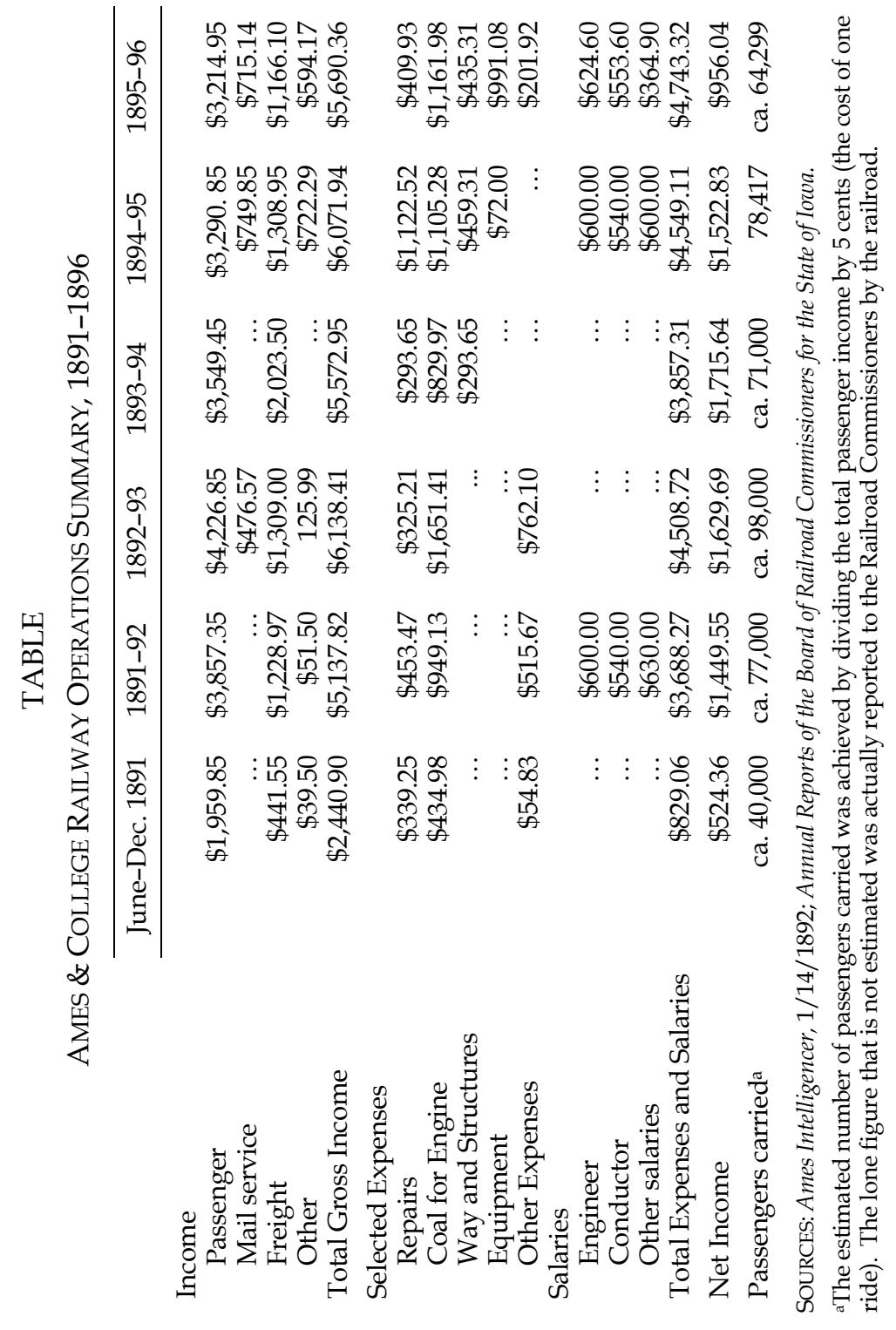


pus. In spite of the depression of the middle 1890s, when national unemployment figures reached an estimated 18.4 percent by 1894, those years saw IAC experience a building boom. Between 1892 and 1896 IAC added two new major structures to campus: Agricultural Hall (now Catt Hall) in 1892 at a cost of $\$ 35,000$, and Margaret Hall, the women's dormitory, in 1895 at a cost of $\$ 45,000$. The college also rebuilt its athletic grounds, laid 6,000 feet of sewer pipe connecting both new and old structures to the college sewage system, and renovated at least nine other structures on campus at a cost of more than $\$ 20,000$. The Dinkey hauled the vast majority of the materials used in the building and renovations. ${ }^{39}$ By 1892 the A\&C found itself hauling so much freight that it added a second steam dummy engine to meet the demand for the college's freight traffic. ${ }^{40}$

Perhaps more importantly, reliable mass transit between the college and city also began to attract the notice of the outside world in the months and years following the Motor Line's founding. The IAC Student reported in September 1891 on the large number of people who visited campus "every day." 41 Many of the visitors were alumni, but farmers, businessmen, and parents of potential students visited campus as well. Most visitors knew where they were, but some visitors to campus seem to have been confused as to that fact. The Student reported one instance when a "young rural couple" traveling through

39. Day, ISU and Its Buildings, 184-87, 337-38, 82. "The Pines" (now called Sloss House), a faculty residence, underwent repair and a remodel in 1894 (ibid., 176). The third floor of the East Boarding Cottage was completely remodeled in 1890 and the lower two floors in 1894 (ibid., 180-81). Both floors of the West Boarding Cottage were completely remodeled in 1894 (ibid., 181). A second floor was added to the Chemical and Physical Laboratory in 1891 (ibid., 2023). The original College Creamery underwent a remodel in 1891 (ibid., 213). The "New" Creamery was built for \$9,000 over 1891 and 1892 (ibid., 214-15). The English Office Building received an addition and remodel in 1892 for $\$ 4,000$ (ibid., 235-36). The Experimental Barn was built for \$4,000 in 1894 (ibid., 240-41), and North Hall was remodeled in 1894 and appended to Margaret Hall (ibid., 363). Some of the costs for remodeling and repair were not recorded, but the material for all of these projects was hauled to campus by the Motor Line.

40. IAC Student, 6/22/1892; Ames Times, 6/23/1892, 7/14/1892.

41. IAC Student, 9/9/1891. 
Ames had taken the Motor Line to campus and made their way to Old Main thinking it a large hotel. ${ }^{42}$

Befitting IAC's position as an agricultural college, it soon began to host meetings of agriculturalists on campus that brought academics and agriculturalists together for the benefit of both. On April 13 and 14, 1892, IAC hosted the annual meeting of Iowa Sheep Farmers and Woolgrowers. The group was relatively small, and the two-day event went well. ${ }^{43}$ The success with sheep encouraged the college to try its hand with dairy cattle; during the winter break from classes in 1892, IAC held the state dairy convention on campus for three days. The program featured some of the most prominent dairymen in the state, leading its organizers to expect a large audience. With the students gone home for winter break, most of the delegates stayed in rooms on campus, and the Motor Line served as the vehicle that brought the delegates from the C\&NW depot to campus and sent them back again. During the conference the Aurora, the monthly IAC newsletter, reported that the Motor Line carried over 1,000 people in a 24 -hour period. The Times gave the event substantial coverage, including speeches by notable dairymen and President Beardshear in its November 17 issue. The paper noted that a "mass of humanity" descended from the C\&NW platform and was transported out to campus by the Motor Line. The report concluded with pride that the event was a great achievement for the city and the college. The dairymen echoed the Times's assessment of the meeting, calling it "a pronounced success from opening to closing." 44

The joining of the city and campus via the Motor Line made it possible for entertainers from the outside world to draw from both segments of the community. For example, John C. Lewis and his vaudeville troupe came to Ames on December 16, 1892,

42. IAC Student, 3/22/1898.

43. The Student printed the two-day program in full and encouraged students to attend. IAC Student, 4/9/1892.

44. Proceedings of the 16th Annual Convention of the Iowa State Dairy Association (Waterloo, 1893), 10 and Secretary's Preface; Aurora, November 1892; Ames Times, 11/17/1892. The first meeting of the conference was held in the Morrill Hall auditorium, which seated 634, and the seats were almost completely filled. Proceedings of the Dairy Association, 9. 
to perform his popular play, Si Plunkard. Lewis was a nationally known director and actor who spent more than 20 years touring the country with Si Plunkard. There is little doubt that Lewis's drama and comedy were written for and played to midwestern sensibilities; his success in spreading his work so far over space and time strongly suggests that the material contained in the production struck a chord with his audiences over the two decades that spanned the turn of the century. His Ames audience that snowy December in 1892 was no exception. To ensure that a college audience would be able to enjoy the entertainment, the A\&C laid on a special motor that departed Ames for campus at 10:40 pm. ${ }^{45}$ No one, it seemed, wanted to miss the fun.

CLEARLY, then, the Motor Line helped to forge Ames and IAC into a single community, but it is also worth noting that contemporaries understood and appreciated that transformation as well as the Dinkey's central role in the process. "The Motor," as contemporaries often called it, rapidly became a central feature in their lives and in the popular culture of the community. The train became a central character in many of their stories, plays, and poetry, and the A\&C's employees became local celebrities. IAC students and townspeople perceived the Motor as a great improvement over what had been before and saw the railway as a symbol of progress in a progressive age. In its last issue for 1892 the IAC Student noted that the "motor line is one of the improvements having the greatest effect on the daily life at the college." 46 In January 1893 the Times ran a commemorative issue that calendared the great achievements in Ames within the past 18 months. Buildings and the new waterworks figured prominently in the list, but the paper listed the Motor Line as one of the most significant improvements in the town. According to the paper, the $A \& C$ was responsible for the economic boom that Ames had experienced over the preceding year-and-a-half. ${ }^{47}$ Even in retrospect the Motor Line stood out in the minds of con-

45. Ames Times, 12/15/1892. See also William Slout, Theatre in a Tent (1972; reprint, New York, 2008), 7.

46. The Student also referred to the Dinkey line as a "modern railroad." IAC Student, 11/9/1892.

47. Ames Times, 5/1/1893. 
temporaries. In 1897, for example, Anna Dean, from the class of 1892, reflected on how she came to campus as a freshman on the old bus but left it as a senior on the "motor car." 48 In November 1891, as IAC's first winter with the Dinkey closed in, President Beardshear noted in his annual report to the college trustees that "the completion of the steam motor railway connecting the college with Ames has greatly benefited our work. It places the college in a more intimate relation with the town and enables us to have mutual interchange in the interests affecting the town, college and State." 49

The Times and the Intelligencer, along with the IAC Student, took a keen interest in all of the activities on the Motor Line, from its construction to the purchase of new equipment, even noting its performance in snowy weather. But perhaps more important, all of the attention the newspapers focused on the A \& C transformed its employees into local celebrities. By far the most significant of these was Henry "Hank" Wilkinson.

Born in Illinois in August 1854, Wilkinson had come with his parents to Boone. He spent 15 years working for the C\&NW before marrying Laura Baughman in 1890. Married life and the desire to start a family meant that Hank no longer wished to roam so far on the rails, so the couple settled in Ontario just west of (now part of) Ames. Wilkinson was a tall and robust man who was always quick to smile; he had a contagious sense of humor and made friends easily. His pleasant countenance combined with his willingness to help anyone in need earned him universal respect, and President Beardshear and his family counted him among their friends. ${ }^{50}$ Contemporaries considered him honest and hard-working. He would see to the safety of nearly two million passengers over the 15 years he served as the conductor on the Motor Line.

The first mention of Wilkinson as conductor on the Motor Line comes from the Times on July 28, 1892.51 Within months he

48. The 1897 Bomb, 143-44.

49. "Report of the President," Fourteenth Biennial Report of the Board of Trustees of the Iowa State Agricultural College and Farm Made to the Governor of Iowa (Des Moines, 1891), 7.

50. I.S.C. Alumnus, December 1914, 11-14.

51. Ames Times, 7/28/1892. 


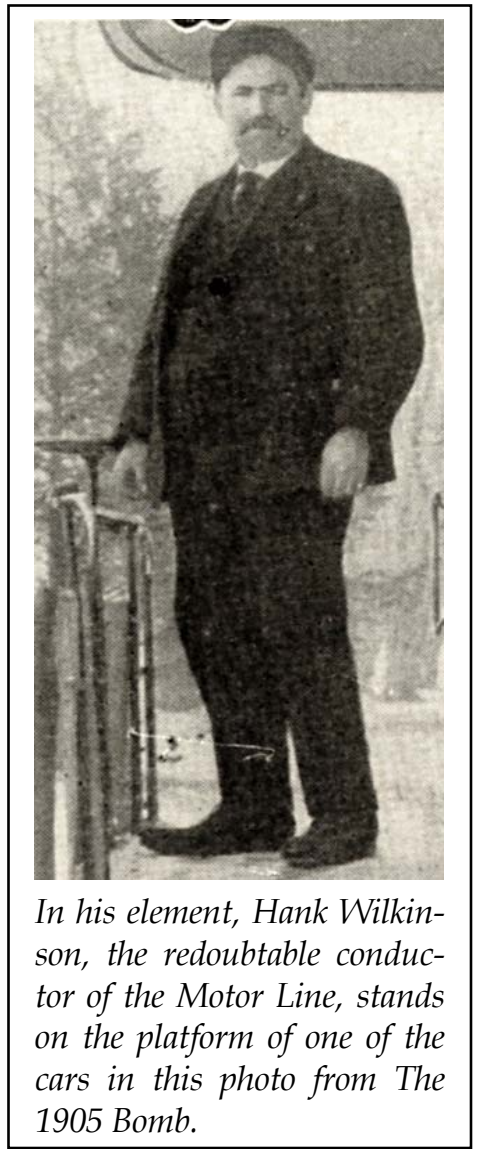

had become a local celebrity. Over the next 15 years the Ames and student newspapers not only chronicled his exploits on the Motor Line; they also noted the birth of his children, reported on his hunting expeditions, took note of his ill health, and mourned with him in times of personal loss. Wilkinson cut quite a dashing figure on the Motor Line, and the Student could not help but be impressed. The paper noted that young men escorting their ladies to chapel all wished to display a "cool self confidence similar to that of 'Hank' boarding the motor." 52

One of the most colorful episodes involving Wilkinson that the newspapers covered occurred in the autumn of 1893 , when the Times reported on a race between the Dinkey and a cow. According to the paper, a lone cow from the IAC farm had somehow gotten out of her pasture and ended up

52. Ames Times, 7/28/1892, 4/12/1894; IAC Student, 4/8/1893, 4/9/1894; Ames Intelligencer, 4/12/1894. The Times, 3/2/1893, happily reported that Hank's wife had delivered an 11-pound baby boy, but noted that "Hank has no time to run the limited on the A\&C Railway." When Wilkinson's daughter was born on September 4, 1894, the Times reported that as well, noting, "all hands getting along nicely." Ames Times, 9/6/1894. The Times, 12/28/1893, reported that Hank's 22-month-old son, John Clayton Wilkinson, had assisted his father on the Motor Line one day the previous week. The Times, 12/15/1892, reported tongue-in-cheek that "sportsmen need not go to the college farm in search of game, for all wild animals in their locality are extinct, largely due to the fact that 'Hank' Wilkinson and Wesley Sexton went hunting out there Tuesday." After serving for 15 years on the Dinkey line, Wilkinson moved on to work at the college. Tragically, he died during an accident while driving a truck for ISC in 1914. Meads, Squaw and Skunk, 36-37. Wilkinson's sudden and untimely death at the age of 60 received much coverage in the Ames and college newspapers. See, for example, Ames Evening Times, 11/20/1914, 11/23/1914. 
near the track. As the train passed the cow on the way up to campus, the animal turned and began to run alongside the engine. As the paper told it, the race between cow and steam engine was a lengthy and closely run affair, but "Hank finally won the heat." After the race, the cow ended up in the wrong pasture, where students found her (apparently no worse for wear) the next morning. 53

Contemporaries clearly noted and enjoyed the papers' coverage of Hank Wilkinson and his colleagues, but there were occasions when students and townspeople rubbed each other the wrong way. One incident that occurred in April 1895 played itself out in the newspapers. The Times reported in a lengthy piece that a group of college boys, "presumably freshmen," had come to town on the Motor and acted in a most inappropriate manner. The paper reported that the group came out from campus to the cafe at the C\&NW depot and caused a ruckus by eating everything the café possessed, annoying the patrons by repetitious yelling of the college cheer, and engaging in "snatches of senseless doggerel, which was entirely uncalled for, and deserving of the severest censure." The IAC Student responded that, in an attempt to be "sensational," the Times's college editor had presented a "pretty highly colored account" of what had actually transpired at the depot. The Times, the IAC Student suggested, should concentrate its reporting on the "good features of I.A.C., rather than fill up [its] columns with criticisms that are both offensive and unjust." 54

The editors of the Times were not about to accept this version of events and in very un-Times-like language took what it called an "obscure college publication" to task for its temerity. The Times wrote that anyone who was acquainted with the events at the depot would, upon reading the story in the IAC Student, be led "to believe that there were several large orifices in the sky-piece of the worthy sage from whose facile pen it had emanated, and that he had better glue them up and talk through something else." 55

53. Ames Times, 10/12/1893.

54. Ames Times, 4/11/1895; IAC Student, 4/16/1895.

55. Ames Times, 4/18/1895. 
Frustrations and frictions between townspeople and students notwithstanding, perhaps the most impressive aspect of the Motor's place in the minds of students is that it shared in the reflected pride that they felt in being students at IAC. In the 1895 Bomb, the junior class president, J. R. Davidson, penned a small piece titled "Iowa Agricultural College, Past and Present." 56 Davidson noted the physical and educational progress that the college had achieved since its founding. It is both instructive as to its impact and indicative of its central role in the life of the campus that the Motor was the rhetorical thread that held a significant portion of Davidson's narrative together. He ended his historical piece with a fictional journey of an imaginary alumnus returning to campus and reflecting on what he found. Davidson noted that in the old days a new student arriving at the C\&NW depot would "wander aimlessly about until he found the college bus." However, Davidson continued,

Those days have passed away. Now, the new student, as he alights from the car [i.e. the train at the C\&NW depot], hears three shrill whistles which come from just northeast of the railway depot. The old students rush by him, and he is then made acquainted with the term "Motor starts in five minutes." He follows the crowd, and boarding the motor is conveyed to the college, where he alights at the neat motor depot, just north of the main building.

As Davidson's story moved on, his fictional alum walked in quiet amazement among the proud new buildings, beautiful park, well-kept athletic grounds, and "neat depot" (the Hub) until the shrill whistle sounded again signaling that it was time to board for the return trip to town. As the alum sat and looked out the window of the passenger car as the Motor chugged back toward town, he reached a "true conclusion. Iowa Agricultural College is a great institution." 57

56. J. R. Davidson was one of the editors of the IAC Student from its founding in 1892 and the president of his junior class. He is listed as an 1895 graduate, but unfortunately Elizabeth Tiernan could find no biographical information on him for her Iowa State College Graduates: A Biographical Dictionary, 1890-1899 (Ames, 1952), 46.

57. The 1895 Bomb, 121-22. Alumni from the 1890s were no less impressed with the institution long after leaving IAC. D. A. Thornburgh (class of 1892) wrote in a letter to The 1908 Bomb, "What an education in itself to come into close, al- 
THE YEAR 1896 brought the initial phase of the unified history of Ames and IAC to an end. In spite of the depression that had begun with the Panic of 1893, Ames was fiscally sound enough to levy a $\$ 12,000$ bond issue to build an electric power plant that finally brought electricity to the city in 1896, and then went on to increase water and sewer services, in addition to negotiating to secure a new C\&NW depot at the end of the century. In 1898 the college changed its name from Iowa Agricultural College to Iowa State College, and in the last years of the century it expanded rapidly, building new buildings and watching enrollment reach nearly 1,000 by 1900 .

Yet the $A \& C$, the backbone of the community and the catalyst for part of this growth, could not keep pace with technological progress. In January 1896 a near-fatal accident with a pedestrian on the Motor Line led to a lawsuit and a sizable judgment against the company. ${ }^{58}$ The A\&C appealed the decision to the Iowa Supreme Court, but the high court sustained the original verdict. Without insurance to cover the cost of the settlement, the burden of meeting the financial obligation imposed by the court fell directly on the shoulders of the investors. Thus, in the late 1890s the A\&C could not afford to modernize its equipment to electric power, and updating the old steam equipment seemed to be a losing proposition in an age when electricity had replaced steam as the preferred mode of power for street railways, so the A\&C continued to operate with increasingly obsolete and potentially dangerous steam equipment.

By 1904 the ISC Student began to print articles openly critical of the Dinkey as being outdated, small, slow, unsafe, and hardly a fit example of a progressive age. ${ }^{59}$ In his report to the trustees at the end of that year, IAC President Albert Storms commented on the Dinkey's shortcomings. The following spring, the trustees began to reconsider their entire relationship with

most intimate contact, with men such as Welch, Beardshear, Lincoln, Stanton, Hainer, Osborn and many others of almost equal power in classroom and in personality. As truly fortunate were the men and women who wrought in the $80^{\prime}$ s and $90^{\prime}$ s."

58. Allen v. Ames and College Railway, 106 Iowa 602, 76 N.W. 848 (Iowa 1898), $1-86$.

59. ISC Student, 1/27/1904, 3/2/1904, 3/5/1904, 3/16/1904, 4/13/1894. 
the A\&C. Since 1903 the Fort Dodge, Des Moines \& Southern Railway had been in negotiations with the city to run electric interurban service from Des Moines through Ames to Fort Dodge. Increasingly, it seemed to the trustees that the old A\&C, with its outdated equipment, was no longer capable of providing ISC with the rapid transit service it needed. On March 8, 1905, the trustees formed a subcommittee to discuss the relationship between the $\mathrm{A} \& \mathrm{C}$ and the college. Meetings between the two took place over the summer, and on September 27, 1905, the subcommittee tendered its report to the trustees, who delivered an ultimatum to the company: either give up steam for electric or gasoline power or move the rail line to the north and away from the heart of campus. ${ }^{60}$

Estimated costs to electrify the Motor Line ran at nearly $\$ 80,000$, a figure well beyond the ability of the A\&C to capitalize. ${ }^{61}$ Thus, the directors of the company worked throughout the autumn of 1905 and spring of 1906 to sell their corporation. In February 1906 the Student reported that the A\&C had been sold to the Newton \& Northwestern Railway (N\&NW), an Iowa railroad backed by eastern moneyed interests that provided electric interurban service from Des Moines to other points within central Iowa. The N\&NW was soon subsumed by the Fort Dodge, Des Moines \& Southern Railway, which continued to operate the steam Dinkey while the new electric interurban rails were laid. At about 10:00 p.m. on Friday, September 6, 1907, the Dinkey made its final run from Ames to the campus and

60. President's Report to the Trustees, 12/23/1904, box 1, RS 2/6, Albert Storms Papers, Special Collections, Iowa State University Library; Trustees' Minutes, Book C, July 1903-January 1907, 3/8/1905, p. 247, and 9/29/1905, pp. 369-72, Special Collections, Iowa State University Library.

61. As they had in 1890, students in 1904 came forward to help try to find a solution. This time two groups of students wrote senior theses as case studies of how to electrify the Motor Line. Both studies estimated that it would cost nearly $\$ 80,000$ to transform the Dinkey from steam to electric power. Arthur R. Buckley, Harold L. Scranton, and Earl O. Shreve, "Design and Specifications for Changing the Present A.\&C.R.R. from Steam to an Electric Road" (undergraduate thesis, Iowa State College, 1904); Frank L. Brown and Lester Morris, "The Ames and College Belt Line" (undergraduate thesis, Iowa State College, 1904). According to the $A \& C^{\prime}$ s financial reports to the Railroad Commission for FY 1902-03, the railroad earned only \$3,269.55 in net profit. Twenty-sixth Annual Report of the Board of Railroad Commissioners for the Year Ending June 30, 1903 (Des Moines, 1903), 30. 
back. ${ }^{62}$ Over its 16-year lifespan it had carried over 2.1 million passengers the 1.98 miles to and from Ames and ISC.

BETWEEN 1891 AND 1896 Ames and Iowa State College became one community bound together by the Ames \& College Railway. What began as an undergraduate senior thesis and a dream of John Stevens became the backbone that held a rapidly growing city and college together. It is hardly surprising that the little railroad, as the only viable alternative to walking or taking the horse-drawn bus, became so important so quickly. Over its first five years of existence the Dinkey carried no fewer than 356,000 passengers between the college (with an average student population of 545 ) and the city (with a population of about 1,800 ). The A\&C brought the college to the world and the world to the college; and it enabled the college and the city to embark on a decade of unparalleled growth in terms of economics, mortar and brick, and population. Contemporaries understood and appreciated the significance of the A\&C. The local media considered events on the Motor Line to be newsworthy and covered them with alacrity. While the frustrations associated with growth and change in the community sometimes played themselves out in the local media, townspeople and students alike took pride in their community's achievements, and the Dinkey played a significant part in their reflections. Even though the inexorable march of technology eventually rendered the Motor Line obsolete, for five years between 1891 and 1896 it helped to forge one community in Ames.

62. ISC Student, 2/24/1906, 9/9/1907; Iowa Trolleys: Bulletin 114 of the Central Electric Railfans' Association (Chicago, 1975), 97-100; George Hilton and John Due, The Electric Interurban Railways in America (Stanford, CA, 1960), 363-64. 